\title{
Comparative Outer Membrane Protein Analysis of High and Low-Invasive Strains of Cronobacter malonaticus
}

\author{
Maha A. Aldubyan ${ }^{1,2}$, Ibtesam S. Almami ${ }^{1,3}$, Fatiha M. Benslimane ${ }^{1,4}$, \\ Abdlrhman M. Alsonosi ${ }^{1}$ and Stephen J. Forsythe ${ }^{1 *}$ \\ ${ }^{1}$ School of Science and Technology, Nottingham Trent University, Nottingham, United Kingdom, ${ }^{2}$ Department of \\ Pharmacology, College of Pharmacy, Qassim University, Al-Qassim, Saudi Arabia, ${ }^{3}$ Biology Department, College of Science, \\ Qassim University, Al-Qassim, Saudi Arabia, ${ }^{4}$ Biomedical Research Institute, Qatar University, Doha, Qatar
}

OPEN ACCESS

Edited by:

Julio Parra-Flores,

University of the Bío Bío, Chile

Reviewed by:

Ariadnna Cruz-Córdova Hospital Infantil de México Federico

Gómez, Mexico

Ömer Akineden,

Justus Liebig Universität Gießen,

Germany

Edward M. Fox

Commonwealth Scientific and Industrial Research Organisation

(CSIRO), Australia

*Correspondence:

Stephen J. Forsythe sforsythe4j@gmail.com

Specialty section:

This article was submitted to

Food Microbiology,

a section of the journal

Frontiers in Microbiology

Received: 31 August 2017 Accepted: 03 November 2017 Published: 17 November 2017

Citation:

Aldubyan MA, Almami IS Benslimane FM, Alsonosi AM and Forsythe SJ (2017) Comparative Outer Membrane Protein Analysis of High and Low-Invasive Strains of

Cronobacter malonaticus.

Front. Microbiol. 8:2268.

doi: 10.3389/fmicb.2017.02268
Cronobacter are an important group of foodborne pathogens that has been linked to life-threatening infections in both infants and adults. The major infections associated with Cronobacter species are neonatal meningitis, necrotizing enterocolitis, and septicaemia. There are seven species in the Cronobacter genus, of which only three are of clinical importance; Cronobacter sakazakii, Cronobacter malonaticus, and Cronobacter turicensis. To date most studies have focussed on C. sakazakii as it is the major species associated with neonatal infections. However, recently C. malonaticus, in particular sequence type 7 (ST7), has been noted as being prevalent in adult infections and therefore warranting further investigation. In this study, eight strains of $C$. malonaticus ST7, that had been isolated from a wide range of sources and varied in their in vitro virulence, were chosen for proteomic analysis of their outer membrane proteins (OMPs). One-dimensional gel analysis revealed a $\sim 29 \mathrm{kDa}$ size band that was only present in the highly invasive strains. Subsequent mass spectrometric analysis identified several peptides that matched the flagellin protein. The presence of flagellin protein was confirmed in 2D gel spot. Mass spectrometry analysis of total OMPs revealed that the four highly invasive C. malonaticus strains expressed the main flagellum proteins that were absent from the four low invasive strains. These were the flagellar hook protein FlgE, flagellar hook-associated protein 1, flagellar hook-associated protein, flagellin, and flagellar hook-filament junction protein FlgL. This data indicates that C. malonaticus flagellar proteins may have an important role in the organism's invasion properties.

Keywords: Cronobacter spp., Cronobacter malonaticus, invasive, outer membrane proteins (OMPs), proteomics, flagellin

\section{INTRODUCTION}

Cronobacter species are Gram-negative, facultative anaerobic rod-shaped bacteria and are members of the Enterobacteriaceae family (Iversen et al., 2008). The genus is closely related to the Enterobacter and Citrobacter genera (Forsythe et al., 2014). Seven Cronobacter species have been identified to date; Cronobacter sakazakii, Cronobacter malonaticus, Cronobacter turicensis, 
Cronobacter universalis, Cronobacter muytjensii, Cronobacter dublinensis, and Cronobacter condimenti (Cetinkaya et al., 2013). They occur in the environment, plant material and subsequently the ingredients of various foods (Forsythe et al., 2014). Cronobacter species have been isolated from a wide range of sources including food, rats, flies, and asymptomatic human carriage has been reported (Kandhai et al., 2004; Friedemann, 2007; Miled-Bennour et al., 2010). The organism has been isolated from the hospital environment and clinical samples, including cerebrospinal fluid, blood, bone marrow, sputum, urine, inflamed appendix, neonatal enteral feeding tubes, and conjunctivae (Iversen and Forsythe, 2003; Hurrell et al., 2009; Holy and Forsythe, 2014).

Cronobacter species are opportunistic pathogens associated with severe neonatal infections; septicaemia, necrotizing enterocolitis, and meningitis (Biering et al., 1989; Joseph and Forsythe, 2011; Holy and Forsythe, 2014). Clinical cases of Cronobacter infection have been reported in all age groups, with the majority being in the adult population (Lai, 2001; Holy et al., 2014; Patrick et al., 2014; Alsonosi et al., 2015). Although infections in infants and neonates are rare, they can have fatal consequences (Caubilla-Barron et al., 2007). The majority of infant and neonatal cases, including outbreaks on neonatal intensive care units, are only associated with the C. sakazakii species (Kucerova et al., 2011; Forsythe et al., 2014), especially the neonatal meningitic pathovar C. sakazakii sequence type 4 (ST4; Joseph and Forsythe, 2011; Hariri et al., 2013). This could be linked to their frequent isolation from infant formula and milk powder manufacturing plants, where $25 \%$ of isolates have been reported to be this pathovar (Sonbol et al., 2013).

Clinical isolates of C. sakazakii are able to adhere and invade intestinal cells and brain cells as well as survive in macrophages (Townsend et al., 2007, 2008; Giri et al., 2012). The organism is able to invade and translocate through intestinal (Caco-2) and brain (HBMEC) cell lines as well as persist and multiply within macrophages and microglial cells (Almajed and Forsythe, 2016). Due to the association of C. sakazakii with infant and neonatal outbreaks, the majority of virulence-related studies have focused only on this species. Consequently, few studies have considered the virulence traits of $C$. malonaticus, which is associated with adult infections and thus the majority of Cronobacter infections (Forsythe et al., 2014).

This study analyzed the outer membrane proteins (OMPs) of eight ST7 C. malonaticus strains, which had been isolated from a wide range of sources and periods. Furthermore, the strains varied in their virulence based on in vitro studies (Alsonosi, 2017).

\section{MATERIALS AND METHODS}

\section{Bacterial Strains and Growth Conditions}

Eight C. malonaticus strains (Table 1) were recovered from storage at $-80^{\circ} \mathrm{C}$ by streaking on Tryptone Soya agar (TSA) and incubating for $18 \mathrm{~h}$ at $37^{\circ} \mathrm{C}$. The strains were then cultured in $400 \mathrm{ml}$ of Tryptone Soya broth (TSB) (CM0131, Oxoid Thermo Fisher) for $18 \mathrm{~h}$ with gentle shaking at $37^{\circ} \mathrm{C}$.
TABLE 1 | Cronobacter malonaticus strains used in this study.

\begin{tabular}{lcllll}
\hline $\begin{array}{l}\text { Strain } \\
\text { number }\end{array}$ & $\begin{array}{c}\text { Sequence } \\
\text { type }\end{array}$ & Source & Country & $\begin{array}{c}\text { Year of } \\
\text { isolation }\end{array}$ & $\begin{array}{l}\text { In vitro } \\
\text { invasion } \\
\text { ability }\end{array}$ \\
\hline $565^{\mathrm{a}}$ & 7 & Fecal isolate & USA & 1973 & High \\
$1558^{\mathrm{b}}$ & 7 & Fecal isolate & Czech Republic & 1980 & High \\
$1827^{\mathrm{C}}$ & 7 & Cannula (Blood) & Czech Republic & 2007 & High \\
$2018^{\mathrm{C}}$ & 7 & Sputum & Czech Republic & 2013 & High \\
$1830^{\mathrm{C}}$ & 7 & Throat swab & Czech Republic & 2007 & Low \\
$1833^{\mathrm{C}}$ & 7 & Faecal isolate & Czech Republic & 2010 & Low \\
$1835^{\mathrm{C}}$ & 7 & Throat swab & Czech Republic & 2012 & Low \\
$2020^{\mathrm{C}}$ & 7 & Fecal isolate & Czech Republic & 2013 & Low \\
\hline
\end{tabular}

${ }^{a}$ Farmer et al. (1980). ${ }^{b}$ Aldova et al. (1983). ' Alsonosi et al. (2015).

\section{Outer Membrane Isolation and Protein Estimation}

Three $400 \mathrm{ml}$ cultures of each C. malonaticus strain were grown then pelleted by centrifugation at $5,000 \times \mathrm{g}$ for $25 \mathrm{~min}$. The pellets were then washed twice with PBS and re-suspended in $5 \mathrm{ml} 10 \mathrm{mM}$ HEPES (Sigma, UK), pH 7.5 with $1 \mu \mathrm{l} / \mathrm{ml}$ protease inhibitor and lysed using a sonicating water bath in ice for $7 \mathrm{~min}$. The membranes were collected by ultracentrifugation (BeckmanCoulter Centrifuge Optima L100XP) at $100,000 \times g$ for $1 \mathrm{~h}$ at $4^{\circ} \mathrm{C}$. The pellets were re-suspended in $5 \mathrm{ml}$ of $10 \mathrm{mM}$ HEPES, $\mathrm{pH} 7.5$ with $1 \mu \mathrm{l} / \mathrm{ml}$ protease inhibitor, using 20-gauge needle, and spun using ultracentrifugation as describe above. The pellet was re-suspended in $4 \mathrm{ml}$ of $1 \%$ (w/v) $N$-lauroylsarcosine (Sigma, $\mathrm{UK}$ ) in $10 \mathrm{mM}$ HEPES, pH 7.5 with $1 \mu \mathrm{l} / \mathrm{ml}$ protease inhibitor, and incubated at $37^{\circ} \mathrm{C}$ for $30 \mathrm{~min}$ with shaking and spun again in ultracentrifugation as describe above. The $N$-lauroylsarcosinetreated membranes were spun at $100,000 \times g$ for $1 \mathrm{~h}$ at $4^{\circ} \mathrm{C}$ and the pellet washed briefly with $1 \mathrm{ml}$ of $10 \mathrm{mM}$ HEPES, $\mathrm{pH}$ 7.5 with $1 \mu \mathrm{l} / \mathrm{ml}$ protease inhibitor. The pellet was re-suspended in $400 \mu \mathrm{l}$ of $10 \mathrm{mM}$ HEPES, $\mathrm{pH} 7.5$ with $1 \mu \mathrm{l} / \mathrm{ml}$ protease inhibitor. The concentration of isolated OMPs were measured by the bicinchoninic acid (BCA) protein assay, based on the method of (Stoscheck, 1990) using a kit from Sigma (Poole, UK). The absorbance of the samples was measured at $570 \mathrm{~nm}$ using a plate reader (Expert 96, Scientific laboratory, UK) and a calibration graph was plotted for protein range $0-1 \mathrm{mg} \mathrm{ml}^{-1}$.

\section{Sodium Dodecylsulphate-Polyacrylamide Gel Electrophoresis (SDS-PAGE)}

The isolated OMPs were separated on $10 \%$ sodium dodecylsulphate-polyacrylamide gel electrophoresis using the method described by Laemmli (1970). Any bubbles generated during preparation were removed by overlaying with isopropanol. Briefly, $50 \mu \mathrm{g}$ OMPs were mixed with $5 \mu \mathrm{l}$ of 6x SDS-sample buffer and boiled for $5 \mathrm{~min}$. After cooling, the denatured samples were loaded in 10\% SDS-gel wells along with $3 \mu \mathrm{l}$ of molecular weight Precision Plus Protein standards (Bio-Rad, UK). Using the Bio-Rad (Bio-Rad Laboratories, USA) apparatus, the gel was subjected to electrophoresis at $175 \mathrm{~V}$ for $1 \mathrm{~h}$. The resolved OMPs were then visualized using InstantBlue 
Protein Stain (Sigma-Aldrich, UK) flowed by destaining with water.

\section{Two-Dimensional Gel Electrophoresis}

Two-dimensional gel electrophoresis was as according to Nirmalan et al. (2004). The OMPs were acetone precipitated, and the protein pellet was dissolved in rehydration buffer containing; $8 \mathrm{M}$ urea, $4 \%(\mathrm{w} / \mathrm{v})$ CHAPS, $50 \mathrm{mM}$ DTT, $0.2 \%(\mathrm{v} / \mathrm{v})$ carrier ampholytes, $0.0002 \%(w / v)$ Bromophenol Blue. In the firstdimension isoelectric focusing, an equal amount of protein was loaded on immobilized $\mathrm{pH}$ gradient (IPG) strips with a $\mathrm{pH}$ range of 3-10 and incubated for $2 \mathrm{~h}$ at room temperature. The gel strips were then focused with a Protean isoelectric focusing cell (BioRad Laboratories, Hercules, USA) and the program was set as follows: rehydrating for $16 \mathrm{~h}$ at $50 \mathrm{~V}$ at $20^{\circ} \mathrm{C}$, focusing at $250 \mathrm{~V}$ for $15 \mathrm{~min}$, followed by $8,000 \mathrm{~V}$ for $2 \mathrm{~h}$. For the second-dimension separation, the IPG strips were equilibrated for $15 \mathrm{~min}$ with $10 \%(\mathrm{w} / \mathrm{v})$ DTT in $10 \mathrm{ml}$ of an equilibration buffer [50 mM Tris base, $\mathrm{pH} 8.8,6 \mathrm{M}$ urea, $30 \%(\mathrm{v} / \mathrm{v})$ glycerol, and $2 \%(\mathrm{w} / \mathrm{v})$ SDS] and for further $15 \mathrm{~min}$ with $25 \%(\mathrm{w} / \mathrm{v})$ iodoacetamide in the equilibration buffer. Each IPG strip was loaded onto a gel of the appropriate percentage of acrylamide, sealed with $1 \%$ $(\mathrm{w} / \mathrm{v})$ agarose, and $10 \%$ polyacrylamide gel electrophoresis was performed as describe above. After electrophoresis, the proteins were fixed and visualized using PlusOne silver staining kit (GE Healthcare life science, UK) according to the manufacturer's suggested protocol then visualized with Biomolecular Imagers (FLA 7000; Life Sciences, UK). For spot intensity comparison, isolated OMPs from three independent replicates were analyzed by Progenesis SameSpots software, UK.

\section{Maldi-TOF/TOF and LC-MS/MS Analysis In Gel Digestion}

The protein bands were excised from either the $10 \%$ polyacrylamide gel or the $2 \mathrm{D}$ gel electrophoresis seconddimension gel. For in gel digestion, the gel bands or spots were excised and cut into $1 \mathrm{~mm}$ pieces. Gel pieces were washed twice with $>10$ volumes of Millipore water $(\sim 200 \mu \mathrm{l})$ for $30 \mathrm{~s}$, to wash out any acetic acid. Gel pieces were destained with freshly prepared $200 \mu \mathrm{l}$ of $100 \%$ methanol and $50 \mathrm{mM}\left(\mathrm{NH}_{4}\right) \mathrm{HCO}_{3}$ $(1: 1 \mathrm{v} / \mathrm{v})$ for $1 \mathrm{~min}$ and then dehydrated for $5 \mathrm{~min}$ at room temperature with $200 \mu \mathrm{l}$ of $100 \%(\mathrm{v} / \mathrm{v})$ acetonitrile in $50 \mathrm{mM}$ $\left(\mathrm{NH}_{4}\right) \mathrm{HCO}_{3}(1: 1 \mathrm{v} / \mathrm{v})$ with vortex. The dehydration solution was removed and 100\% (v/v) acetonitrile was added and incubated for $30 \mathrm{~s}$ or until the gel pieces shrunk. Then the buffer was removed and the gel pieces were left to air dry. For reduction and alkylation, gel pieces were rehydrated with $100 \mu \mathrm{l}$ of freshly prepared $25 \mathrm{mM}$ DTT (Sigma, UK) in $50 \mathrm{mM}\left(\mathrm{NH}_{4}\right) \mathrm{HCO}_{3}$ and were incubated for $20 \mathrm{~min}$ at $56^{\circ} \mathrm{C}$. Buffer was removed and replaced with $100 \mu \mathrm{l}$ of freshly prepared $55 \mathrm{mM}$ iodoacetamide (Sigma, UK) in $50 \mathrm{mM}\left(\mathrm{NH}_{4}\right) \mathrm{HCO}_{3}$ solution and incubated in the dark for $15 \mathrm{~min}$ at $25^{\circ} \mathrm{C}$. The gel pieces were once more dehydrated by $200 \mu \mathrm{l}$ of $100 \%(\mathrm{v} / \mathrm{v})$ acetonitrile in $50 \mathrm{mM}$ $\left(\mathrm{NH}_{4}\right) \mathrm{HCO}_{3}(1: 1 \mathrm{v} / \mathrm{v})$ with vortex. The dehydration solution was removed and 100\% (v/v) acetonitrile was added and mixed for $30 \mathrm{~s}$ until the gel pieces shrank. Acetonitrile was then removed and the gel pieces were dried by removing excess liquid and left to air dry.

\section{Trypsin Digestion}

Proteins in the gel pieces were digested with trypsin overnight at $37^{\circ} \mathrm{C}$ in $20 \mu \mathrm{l}$ of digestion solution containing $12 \mathrm{ng} / \mu \mathrm{l}$ trypsin gold (Promega, UK) in 0.01\% ProteaseMAX ${ }^{\mathrm{TM}}$ Surfactant:50 mM $\left(\mathrm{NH}_{4}\right) \mathrm{HCO}_{3}$. The reaction was terminated by adding $0.5 \%$ $(\mathrm{v} / \mathrm{v})$ trifluroacetic acid (TFA) to a final concentration of $0.5 \%$ $(\mathrm{v} / \mathrm{v})$ then mixing for $5 \mathrm{~min}$. Digested proteins were recovered by centrifugation for $10 \mathrm{~min}$ at maximum speed $\sim 8,000 \times \mathrm{g}$ (Scientific Laboratory, UK). The supernatant containing the digestion solution was transferred to a new tube. The sample was then ready for LC-based mass analysis.

\section{In Solution Digestion with Trypsin}

From all OMP extracts, $50 \mu \mathrm{g}$ of proteins were precipitated in acetone. The protein pellets were dissolved in solubilization buffer containing $0.2 \%$ ProteaseMAX ${ }^{\mathrm{TM}}$ surfactant in $50 \mathrm{mM}$ $\left(\mathrm{NH}_{4}\right) \mathrm{HCO}_{3}(1: 1 \mathrm{v} / \mathrm{v})$. The protein pellets were then incubated with solubilization buffer in an orbital shaker at $140 \mathrm{rpm}$ for $10 \mathrm{~min}$. A final volume of $93.5 \mu \mathrm{l}$ was reached by adding $50 \mathrm{mM}$ $\left(\mathrm{NH}_{4}\right) \mathrm{HCO}_{3}$. The protein samples were subsequently incubated with $1 \mu \mathrm{l}$ of $0.5 \mathrm{M}$ DTT in $50 \mathrm{mM}\left(\mathrm{NH}_{4}\right) \mathrm{HCO}_{3}$ at $56^{\circ} \mathrm{C}$ for $20 \mathrm{~min}$. Afterwards, $2.7 \mu \mathrm{l}$ of $55 \mathrm{mM}$ iodoacetamide in $50 \mathrm{mM}$ $\left(\mathrm{NH}_{4}\right) \mathrm{HCO}_{3}$ was added and sample tubes were incubated in the dark at $25^{\circ} \mathrm{C}$ for $15 \mathrm{~min}$. A total of $1 \mu \mathrm{l}$ of $1 \%$ ProteaseMAX ${ }^{\mathrm{TM}}$ Surfactant and $1.8 \mu \mathrm{l}$ of $1 \mu \mathrm{g} / \mu \mathrm{l}$ trypsin were then added and the protein samples were incubated overnight at $37^{\circ} \mathrm{C}$. The reaction was terminated by adding $0.5 \%(\mathrm{v} / \mathrm{v})$ TFA and mixed for $5 \mathrm{~min}$, this raised the final volume to $100 \mu \mathrm{l}$. Digested proteins were recovered by centrifugation for $10 \mathrm{~min}$ at max speed $\sim 8,000 \times \mathrm{g}$ (Scientific Laboratory, UK).

\section{Peptide Purification and Proteomic Analysis}

Digested peptides from 2D gel spots were purified using ZipTip- $\mathrm{C}_{18}$ columns (Millipore, UK) which contained $0.5 \mu \mathrm{l}$ of immobilized chromatography media $(\mathrm{C} 18$, resin) at their distal end for sample clean-up before spotting onto a MALDI plate. The Zip-Tip was washed five times with $0.1 \%(\mathrm{v} / \mathrm{v})$ TFA in acetonitrile, followed with five times wash with $0.1 \%(\mathrm{v} / \mathrm{v})$ TFA in 1:1 acetonitrile: water. The Zip-Tip was equilibrated twice with $0.1 \%(\mathrm{v} / \mathrm{v})$ TFA in water and the digested peptides were passed through the Zip-Tips repeatedly by pipetting in and out to bind the sample to the resin. This was followed by washing three times with $0.1 \%$ TFA and $5 \%(\mathrm{v} / \mathrm{v})$ methanol in water to remove unbound material. The sample was eluted directly from the ZipTip in $3 \mu \mathrm{l}$ of $80 \%(\mathrm{v} / \mathrm{v})$ acetonitrile through 15 aspirating and dispensing cycles. A $1 \mu$ l volume of eluted sample was mixed with $1.1 \mu \mathrm{l}$ of matrix, typically alpha-cyano-4-hydroxycinnamic acid in $0.1 \%(\mathrm{v} / \mathrm{v})$ TFA $80 \%(\mathrm{v} / \mathrm{v})$ acetonitrile and spotted in triplicate on the MALDI-TOF sample plate and were analyzed using a MALDI-TOF-MS (UltrafleXtreme, Bruker Daltonics, Germany).

Peptide Mass Fingerprint (Mascot) was searched assuming the digestion enzyme trypsin, Mass values was Monoisotopic, Peptide Mass Tolerance; \pm 100 ppm, Peptide Charge State; 1+, Max Missed Cleavages; 1 variable modification; Oxidation 
(M) and fixed was Carbamidomethyl (C). Data was search at NCBIprot and taxonomy was defined for Proteobacteria (Cottrell, 2011).

The full OMP protein profiling was on LC-MS/MS (Eksegent 400 LC hyphenated to the SCIEX 5600 triple-TOF, USA), LCfractions were controlled using WARP-LC software (version 3.2, Bruker Daltonics) and FlexControl software (version 3.3, Bruker Daltonics). A total of either $1 \mu \mathrm{l}$ or a maximum load of $3 \mu \mathrm{l}(0.5 \mu \mathrm{l}$ or $1.5 \mu \mathrm{g}$, respectively) of the digested proteins was injected and the data acquired were searched against a $C$. sakazakii database in SWISSPROT using MASCOT (version 2.3 servers, Matrix Science). Data generated from the $3 \mu$ l injection gave better protein query converge and as such was used for the comparative analysis.

\section{Motility Test}

Twenty grams of Luria Bertani (LB) broth (Sigma Aldrich, UK) and $0.4 \%$ of agar technical (Thermo Fisher Scientific, UK) were dissolved in $1,000 \mathrm{ml}$ of distilled water and then $5 \mathrm{ml}$ of $1 \%$ triphenyl-tetrazolium chloride (TTC) solution (Fluka, UK) was added. The mixture was autoclaved at $121^{\circ} \mathrm{C}$ under $15 \mathrm{psi}$ pressure for $15 \mathrm{~min}$. After autoclaving, the media was dispensed aseptically into Petri dishes. One colony of fresh TSA culture was inoculated into $5 \mathrm{ml}$ of TSB and incubated in a shaking incubator at $37^{\circ} \mathrm{C}$ for $18 \mathrm{~h}$. Three microliters of each overnight culture broth was inoculated into the center of the TTC-LB agar and incubated overnight at $37^{\circ} \mathrm{C}$. Salmonella Enteritidis and
Klebsiella pneumoniae were used as positive and negative motility controls, respectively.

\section{RESULTS}

In order to identify any differences in the OMP profiles between the eight C. malonaticus strains, their OMPs were extracted and separated using 10\% SDS-PAGE (Figure 1). The SDS-PAGE profiles of isolated OMPs from the eight $C$. malonaticus strains revealed the presence of several proteins bands with molecular weights ranging from 150 to $20 \mathrm{kDa}$. The general protein banding pattern was similar for all C. malonaticus strains. However, one dominant band of size $\sim 29 \mathrm{kDa}$ was only present in four $C$. malonaticus strains $(5065,1556,1827$, and 2018), and coincided with their higher invasive ability (Table 1).

In order to gain a better resolution and to explore the differences in the OMP profiles of the C. malonaticus strains, the isolated OMPS from one highly invasive C. malonaticus strain (1827) and one low invasive strain (1830) were subjected to further detailed analysis using 2D-PAGE and visualized by silver staining (Figure 2). Strains 1827 and 1830 were chosen as they have the highest and lowest invasion properties, respectively.

Comparison between the two gels identified eight spots, out of 40 , that were different between the two strains. These appeared only in the highly invasive C. malonaticus strain (1827) gel or their expression level was either higher or lower as compared to the low invasive strain (1830). Eight spots were picked from

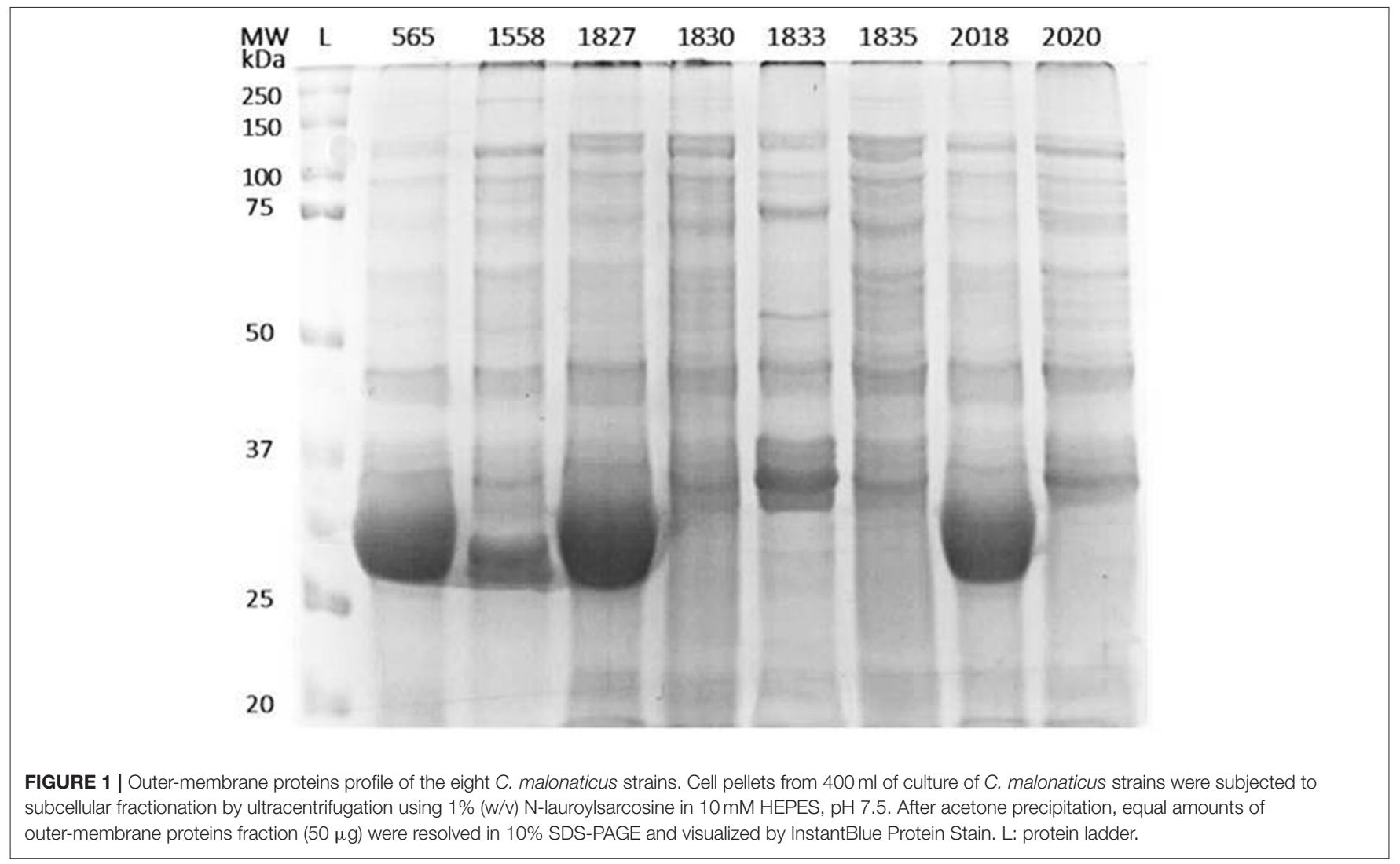


each gel for identification by MALDI-TOF/TOF. Two out of the eight protein spots (beta-lactamase, and flagellar export ATPase FliL; spots five and six, Figure 2) in the highly invasive $C$. malonaticus strain, 1827, showed over a 2.5 fold increase in intensity compared to the low invasive strain, 1830. In contrast, three protein spots (dihydroorotase, ABC transported substratebinding protein, and a hypothetical protein) of the low invasive strain showed a significant lower intensity ( $\geq 2$-fold) compared to the highly invasive strain. Spot 7 in the 1827 strain gel was identified as Flagellin, however the same spot in the 1830 strain gel (spot 9, Figure 2) was identified as NADP-dependent 3hydroxy acid dehydrogenase. Overall, spot analysis revealed nine proteins that are different between the two strains; seven that differ in their expression level and two specific to each strain
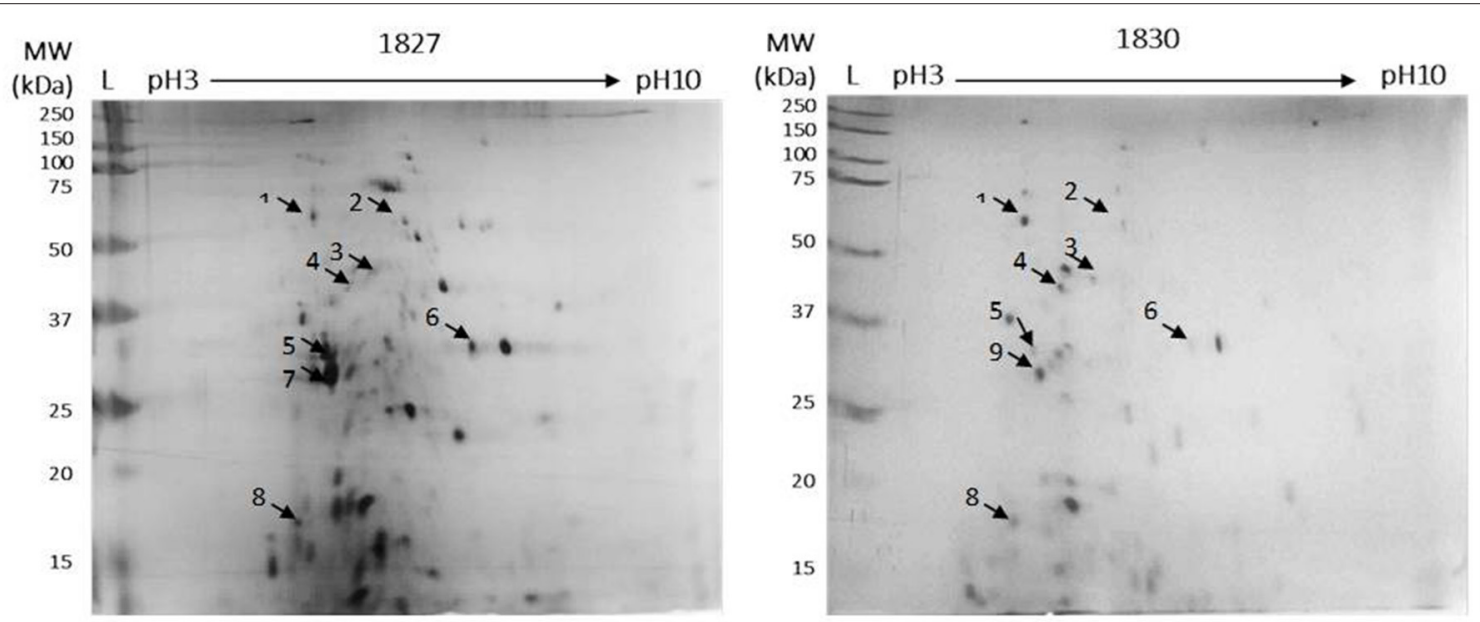

FIGURE 2 | Detection of OMPs for C. malonaticus 1827 (highly invasive) and C. malonaticus 1830 (low invasive) using 2D-PAGE. For the first-dimension of isoelectric focusing, outer-membrane proteins $(50 \mu \mathrm{g})$ was loaded onto immobilized pH gradient (IPG) strips with a pH range of 3-10. After subsequent SDS-PAGE in the second dimension, the proteins were fixed and visualized using silver stain. Arrows indicated to selected spot for quantification and identification.

TABLE 2 | Protein spots identified by MALDI-TOF/TOF mass spectrometer and relevant fold change.

\begin{tabular}{|c|c|c|c|c|c|c|c|c|c|c|}
\hline Spot No. ${ }^{a}$ & Predicted protein & $\begin{array}{l}\text { Mascot } \\
\text { score }^{b}\end{array}$ & Accession no. & $\begin{array}{c}\text { Calculated } \\
\mathrm{pl}^{\mathrm{C}}\end{array}$ & $\begin{array}{l}\text { Mass } \\
(k D a)\end{array}$ & $\begin{array}{c}\text { Sequence } \\
\text { coverage (\%) }\end{array}$ & $\begin{array}{l}\text { Matched } \\
\text { peptide }^{d}\end{array}$ & $\begin{array}{l}\text { Protein } \\
\text { localization }\end{array}$ & $\begin{array}{l}\text { Fold } \\
\text { change }^{e}\end{array}$ & Anova $(p)^{f}$ \\
\hline 1 & Dihydroorotase & 92 & SFI68846 & 5.22 & 45.46 & 31 & 11 & Cytoplasm & $2.1 \downarrow$ & $0.017^{\star}$ \\
\hline 2 & $\begin{array}{l}\text { ABC transporter } \\
\text { substrate-binding protein }\end{array}$ & 91 & BAR60569.1 & 6.93 & 60.58 & 42 & 18 & $\begin{array}{l}\text { Periplasmic } \\
\text { component }\end{array}$ & $1.0 \downarrow$ & 0.899 \\
\hline 3 & Hypothetical protein & 90 & WP_036288432 & 5.35 & 28.87 & 46 & 13 & Unknown & $1.9 \downarrow$ & $0.045^{\star}$ \\
\hline 4 & $\begin{array}{l}\text { Histidinol-phosphate } \\
\text { transaminase }\end{array}$ & 89 & WP_046605311.1 & 6.27 & 39.40 & 43 & 11 & Cytoplasm & $2.8 \downarrow$ & $0.002^{*}$ \\
\hline 5 & Beta-lactamase SHV-6 & 92 & P96348 & 7.04 & 28.25 & 49 & 12 & $\begin{array}{l}\text { Periplasmic } \\
\text { component }\end{array}$ & $2.5 \uparrow$ & $2.127 e-007^{*}$ \\
\hline 6 & $\begin{array}{l}\text { Flagellar protein export } \\
\text { ATPase Flil }\end{array}$ & 79 & WP_064564339.1 & 5.91 & 48.73 & 26 & 8 & $\begin{array}{l}\text { Outer } \\
\text { membrane }\end{array}$ & $2.9 \uparrow$ & $5.728 \mathrm{e}-004^{*}$ \\
\hline 7 & Flagellin & 91 & SAY43719.1 & 5.11 & 36.76 & 22 & 7 & $\begin{array}{l}\text { Outer } \\
\text { membrane }\end{array}$ & - & \\
\hline 8 & $\begin{array}{l}\text { DUF3313 } \\
\text { domain-containing protein }\end{array}$ & 88 & WP_007946360 & 8.61 & 24.29 & 42 & 7 & $\begin{array}{l}\text { Outer } \\
\text { membrane }\end{array}$ & $1.1 \uparrow$ & 0.637 \\
\hline 9 & $\begin{array}{l}\text { NADP-dependent } \\
\text { 3-hydroxy acid } \\
\text { dehydrogenase }\end{array}$ & 90 & ODU73239 & 7.08 & 26.53 & 40 & 7 & $\begin{array}{l}\text { Periplasmic } \\
\text { component }\end{array}$ & - & \\
\hline
\end{tabular}

${ }^{a}$ Number refers to the spot of interest selected from 2D-PAGE, as given in Figure 2.

${ }^{b}$ Protein scores greater than 68 are significant $(p<0.05)$.

${ }^{c}$ /soelectric point of predicted protein calculated from sequence.

${ }^{d}$ Number of peptide matched to predicted protein sequence.

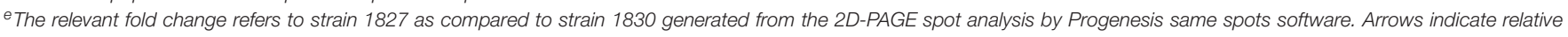
increase and decrease of spot intensity.

${ }^{f}$ Anova (p) values of three accumulated 2D-PAGE analyzed by Progenesis same spots software; ${ }^{*} P<0.05$ was regarded as significant.

- Absent protein. 
(Table 2). Since the predicted size of the protein spot number 7 is not similar to the actual size, this spot was also identified using LC-MS-MS.

In order to analyse the full OMP profile, which would enable a comprehensive comparison between the studied strains, 1.5 $\mu \mathrm{g}$ of total OMP extracted from triplicates of the eight $C$. malonaticus strains were analyzed by LC-MS/MS. The majority of the identified proteins were shown to be known OMPs, with the remainder being defined as either uncharacterized proteins or hypothetical proteins with unknown function. The latter's identity was annotated via high sequence similarity using NCBI's protein BLAST database (Table 3). All proteins present within the strains were compared, revealing five flagellar proteins that only appeared in the four highly invasive strains. This included flagellar hook protein (FlgE), flagellar hook-associated protein 1, flagellar hook-associated protein 2 (also known as the flagellar cap protein), flagellin (FliC), and flagellar hook-filament junction protein (FlgL).

Two chaperon proteins $[60 \mathrm{kDa}$ chaperonin (GroEL) and 10 $\mathrm{kDa}$ chaperonin (GroS)] and two small ribosomal proteins (50S

TABLE 3 | OMP content identified for eight Cronobacter malonaticus strains analyzed by LC-MS/MS.

\begin{tabular}{|c|c|c|c|c|c|c|c|c|c|c|}
\hline \multirow[t]{2}{*}{ Protein names } & \multicolumn{4}{|c|}{ Highly invasive } & \multicolumn{4}{|c|}{ Low invasive } & \multirow[t]{2}{*}{ Notes } & \multirow[t]{2}{*}{ MW (kDa) } \\
\hline & 565 & 1558 & 1827 & 2018 & 1830 & 1833 & 1835 & 2020 & & \\
\hline $50 S$ ribosomal protein L11 & & $x$ & & $x$ & $x$ & $x$ & & $x$ & & 14.749 \\
\hline $\begin{array}{l}\text { Enolase (2-phospho-D-glycerate hydro-lyase, } \\
\text { 2-phosphoglycerate dehydratase) }\end{array}$ & & $x$ & $x$ & $x$ & $x$ & & $x$ & $x$ & & 45.55 \\
\hline Flagellar hook protein FlgE & $x$ & $x$ & $x$ & $x$ & & & & & & 42.48 \\
\hline Flagellar hook-associated protein 1 & $x$ & $x$ & $x$ & $x$ & & & & & & 58.438 \\
\hline $\begin{array}{l}\text { Flagellar hook-associated protein } 2 \text { (Flagellar cap } \\
\text { protein) }\end{array}$ & $x$ & $x$ & $x$ & $x$ & & & & & Flagellar filament capping protein FliD & 49.306 \\
\hline Flagellin (FliC) & $x$ & $x$ & $x$ & $x$ & & & & & & 28.84 \\
\hline LPS-assembly lipoprotein LptE & & & & & $x$ & & & & & 20.17 \\
\hline Outer membrane protein assembly factor BamA & & & & & $x$ & & & & & 89.08 \\
\hline Outer membrane protein assembly factor BamB & & & & & $x$ & & & & OmpA family lipoprotein & 41.18 \\
\hline Outer membrane protein assembly factor BamD & & & & & $x$ & & & & & 27.57 \\
\hline Uncharacterized protein & $x$ & $x$ & $x$ & $x$ & $x$ & & & $x$ & Transcriptional regulator & 12.178 \\
\hline Uncharacterized protein & $x$ & $x$ & $x$ & $x$ & $x$ & $x$ & & $x$ & Hypothetical protein & 18.018 \\
\hline Uncharacterized protein & & & & $x$ & & & & $x$ & Hypothetical protein & 8.08 \\
\hline Uncharacterized protein & $x$ & $x$ & & $x$ & $x$ & $x$ & & $x$ & Hypothetical protein & 12.37 \\
\hline Uncharacterized protein & $x$ & $x$ & $x$ & $x$ & & & & & $\begin{array}{l}\text { Flagellar hook-filament junction } \\
\text { protein FlgL }\end{array}$ & 34.4 \\
\hline Uncharacterized protein & & $x$ & $x$ & $x$ & $x$ & & & $x$ & Lipoprotein & 67.13 \\
\hline Uncharacterized protein & & $x$ & $x$ & $x$ & $x$ & $x$ & $x$ & $x$ & Manganese catalase & 32.7 \\
\hline Uncharacterized protein & & $x$ & & $x$ & $x$ & $x$ & & $x$ & membrane protein & 10.921 \\
\hline Uncharacterized protein & & $x$ & & & & & & & MltA-interacting protein MipA & 27.555 \\
\hline Uncharacterized protein & $x$ & $x$ & $x$ & $x$ & $x$ & $x$ & & $x$ & Murein lipoprotein & 8.4 \\
\hline Uncharacterized protein & & $x$ & & & & & & & $\begin{array}{l}\text { Nucleoside-specific channel-forming } \\
\text { protein Tsx precursor }\end{array}$ & 33.09 \\
\hline Uncharacterized protein & & & & & $x$ & & & & OmpA family lipoprotein & 22.186 \\
\hline Uncharacterized protein & $x$ & $x$ & $x$ & $x$ & $x$ & $x$ & $x$ & $x$ & Outer membrane protein $X$ & 18.113 \\
\hline Uncharacterized protein & $x$ & $x$ & $x$ & $x$ & $x$ & $x$ & & $x$ & $\begin{array}{l}\text { Peptidoglycan-associated outer } \\
\text { membrane lipoprotein }\end{array}$ & 18.7 \\
\hline Uncharacterized protein & $x$ & $x$ & $x$ & & $x$ & & $x$ & $x$ & Phosphoporin PhoE & 41.37 \\
\hline Uncharacterized protein & $x$ & $x$ & $x$ & $x$ & $x$ & $x$ & $x$ & $x$ & Porin OmpA & 38.35 \\
\hline Uncharacterized protein & & $x$ & $x$ & $x$ & $x$ & $x$ & & $x$ & YciE/YciF family protein & 19.06 \\
\hline UPF0325 protein ESA_03178 & & $x$ & & $x$ & $x$ & $x$ & & $x$ & Hypothetical protein & 15.06 \\
\hline 60 kDa chaperonin (GroEL) & $x$ & $x$ & $x$ & $x$ & $x$ & $x$ & $x$ & $x$ & & 57.18 \\
\hline 10 kDa chaperonin (GroS) & $x$ & $x$ & $x$ & $x$ & $x$ & $x$ & $x$ & $x$ & & 10.25 \\
\hline $50 S$ ribosomal protein (rplL) & $x$ & $x$ & $x$ & $x$ & $x$ & $x$ & $x$ & $x$ & & 12.23 \\
\hline $30 S$ ribosomal protein S3 (rpsC) & $x$ & $x$ & $x$ & $x$ & $x$ & $x$ & $x$ & $x$ & & 25.82 \\
\hline Elongation factor Tu & $x$ & $x$ & $x$ & $x$ & $x$ & $x$ & $x$ & $x$ & & 43.42 \\
\hline
\end{tabular}

$x$, Indicates protein present. 
ribosomal protein RplL and 30S ribosomal protein S3 RpsC), and one synthesized protein (Elongation factor $\mathrm{Tu}$ ) were also identified.

There were differences in the OMP profile of the low invasive strains. The majority of OMPs in C. malonaticus 1830 were the OMP assembly factor proteins BamA, BamB, and BamD as well as the LPS-assembly lipoprotein LptE. These were absent from the other three low invasive strain (Table 3).

Since flagellar-related proteins were shown to be present only in the highly invasive $C$. malonaticus strains, a motility test was performed to determine the motility of the eight strains. This confirmed that the four high invasive strains were motile while the low invasive strains were non-motile (Figure 3). There was some difference in the extent of motility with strain 1558 showing a smaller zone of growth than the other strains.
To further investigate the variation in OMP profile, the OMPs were selectively picked from SDS-PAGE gels and analyzed by LC-MS/MS. For reproducibility, OMPs of the two selected strains (1827 and 1830) along with two further strains (1558 and 2020, high and low invasive strains, respectively) were isolated from three independent extractions and subjected to SDS-PAGE analysis (Figure 3A). The major different band corresponded to size $\sim 29 \mathrm{kDa}$, along with eight other bands were analyzed by LC-MS/MS for each strain. The mass spectrophotometry results identified no more than two proteins within single bands.

Proteins with a high sequence coverage following peptide mapping are listed in Table 4, along with their molecular weight and biological function. The predicted molecular weight of the proteins is shown corresponding with size of excised band (Figure 3B). The band of size $\sim 29 \mathrm{kDa}$ that was specifically

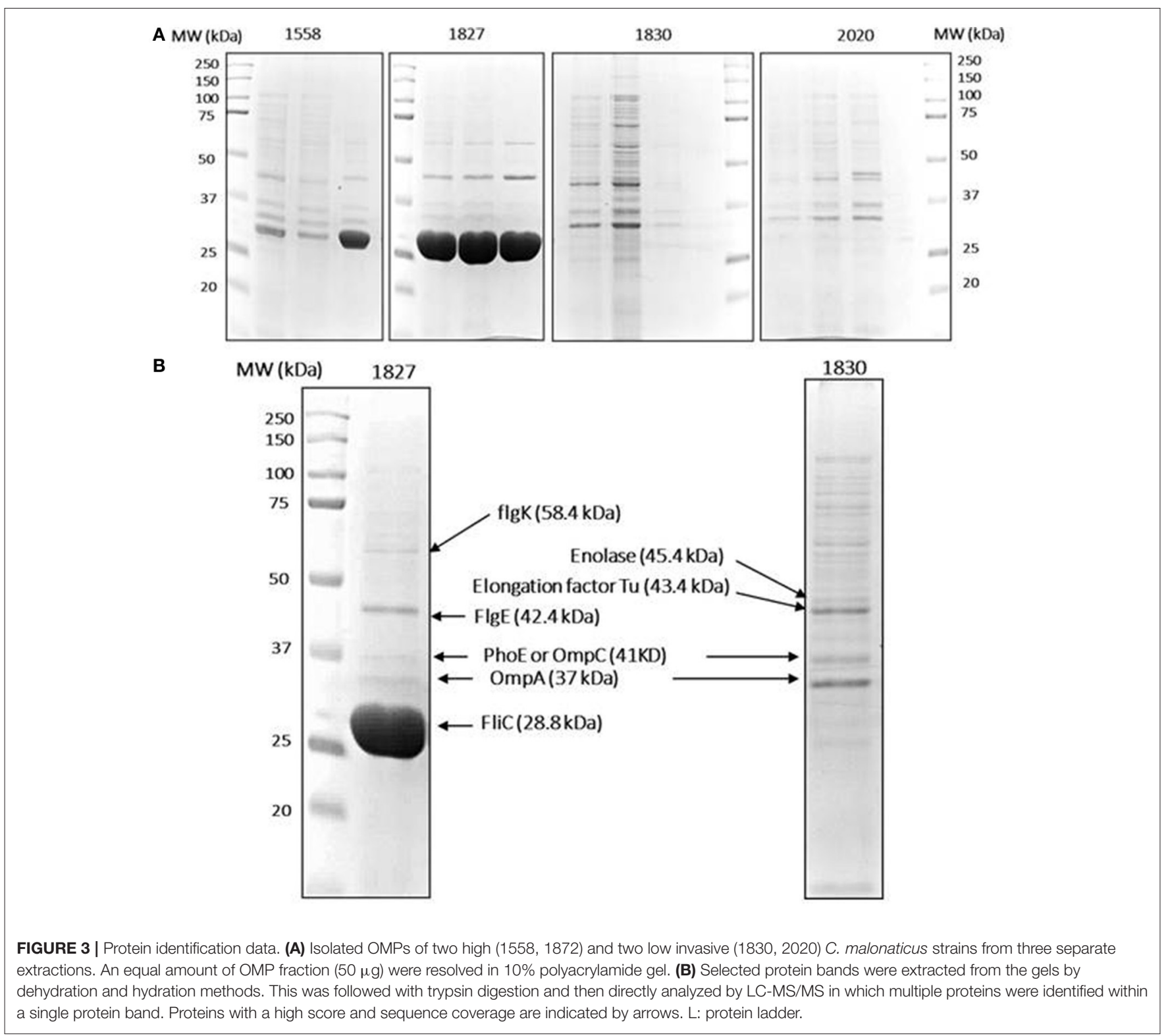


present only in the highly invasive strain (Figure 1) was identified as flagellin (FliC). Flagellar hook-associated protein 1 (FlgK) and flagellar hook protein (FlgE) of band size $\sim 58$ and $\sim 43 \mathrm{kDa}$, respectively, are two further proteins which were identified in the highly invasive strains. Two bands of size $\sim 37$ and $\sim 35$ $\mathrm{kDa}$ were present in both high and low invasive strains. These are listed in Table 4 as uncharacterized proteins, and therefore their sequences were further searched using a protein BLAST search of the NCBI database. The results predicted that the band of size $\sim 37 \mathrm{kDa}$ was phospho-porin (PhoE) belonging to outer membrane porin protein $\mathrm{C}$, while the band of size $\sim 35 \mathrm{kDa}$ was OmpA. Enolase and elongation factor $\mathrm{Tu}$ were identified as the $\sim 45$ and $\sim 43 \mathrm{kDa}$ bands excised from the SDS-PAGE of the low invasive strains.

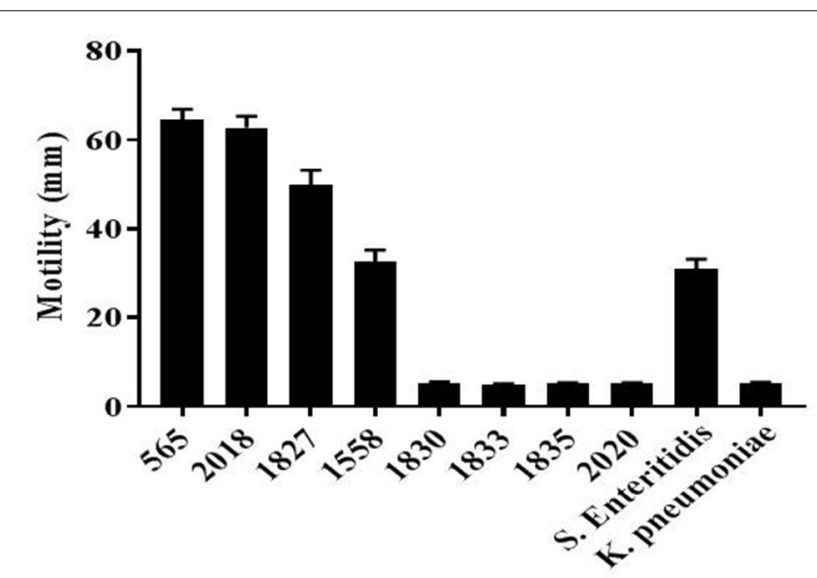

Strains

FIGURE 4 | Motility of $C$. malonaticus strains. For each strains, $3 \mu$ l of freshly inoculated colonies that were grown in TSB at $37^{\circ} \mathrm{C}$ for $18 \mathrm{~h}$ were inoculated into the center of a TTC-LB agar and incubated overnight at $37^{\circ} \mathrm{C}$. The diameter for the motility zone was measured in millimeters. Salmonella Enteritidis and Klebsiella pneumoniae were used as positive and negative, respectively, motility controls. TSB, Tryptone Soya broth; TTC-LB,

Triphenyl-Tetrazolium Chloride-Luria Bertani.

\section{DISCUSSION}

The most reported Cronobacter species in clinical cases are $C$. sakazakii and C. malonaticus in infant and adults, respectively. Most reported studies on Cronobacter have focused on $C$. sakazakii as it is well known with respect to outbreaks of severe infant infections (necrotizing enterocolitis and meningitis) in neonatal intensive care units. However, the majority of Cronobacter infections are in the adult population with various symptoms including urinary tract infections, for which $C$. malonaticus is the more prevalent species isolated (Forsythe et al., 2014; Holy and Forsythe, 2014; Patrick et al., 2014). Although a number of virulence traits have been proposed which may account for the pathogenicity of $C$. sakazakii, there have been fewer studies using C. malonaticus.

Cruz-Córdova et al. (2012) published on the induction of pro-inflammatory cytokines in macrophage by the flagella from five species of Cronobacter. Their detailed analysis used strains of C. sakazakii ST1 and ST4, which are the major pathovars of infant infections. However, they did include the flagellar protein Flic from the $C$. malonaticus type strain (LMG23826 ${ }^{\mathrm{T}}$, sequence type 7) for comparative purposes. This strain generated more IL- 8 release and less TNF- $\alpha$ release from macrophages than the $C$. sakazakii strains, but was not studied further. With respect to surface proteins and cytopathogenicity, Alzahrani et al. (2015) identified 18 outer membrane vesicle associated proteins in a strain of $C$. sakazakii using mass spectrometry. The results indicated that C. sakazakii outer membrane vesicles could play a role in pathogenesis by delivering bacterial toxins into host epithelial cells, driving proliferative, and proinflammatory responses. Unfortunately, the study did not extend to C. malonaticus.

The accelerating advancement in microbial genomics has helped in the identification of bacterial virulence factors and genes involved in pathogenicity. Nevertheless, differences in pathogenicity can be due to expression differences which are not easily determined using comparative genomic analysis. Thus, the proteomic approach has been applied in this study to compare these eight isolated Cronobacter malonaticus strains which were

TABLE 4 | Selected OMPs identified from C. malonaticus isolates 1827 or 1830 as analyzed by LC-MS/MS.

\begin{tabular}{|c|c|c|c|}
\hline Predicted protein name & $\begin{array}{c}\text { Sequence } \\
\text { coverage }(\%)\end{array}$ & Function or family & MW (kDa) \\
\hline Flagellar hook protein FlgE & 48.41 & Belongs to the flagella basal body rod proteins family & 42.4 \\
\hline Flagellar hook-associated protein $1 \mathrm{FlgK}$ & 51.63 & Belongs to the flagella basal body rod proteins family & 58.4 \\
\hline $\begin{array}{l}\text { Enolase (2-phospho-D-glycerate hydro-lyase, } \\
\text { 2-phosphoglycerate dehydratase) }\end{array}$ & 41.44 & $\begin{array}{l}\text { Catalyzes the reversible conversion of 2-phosphoglycerate into phosphoenolpyruvate. } \\
\text { It is essential for the degradation of carbohydrates via glycolysis. }\end{array}$ & 45.4 \\
\hline Elongation factor Tu & 60.41 & $\begin{array}{l}\text { This protein promotes the GTP-dependent binding of aminoacyl-tRNA to the A-site of } \\
\text { ribosomes during protein biosynthesis }\end{array}$ & 43.4 \\
\hline Uncharacterized protein ${ }^{\mathrm{a}}$ & 54.47 & Belongs to the ompA family; Contains OmpA-like domain & 37 \\
\hline Flagellin (FliC) & 84.89 & $\begin{array}{l}\text { Flagellin is the subunit protein, which polymerizes to form the filaments of bacterial } \\
\text { flagella }\end{array}$ & 28.8 \\
\hline Uncharacterized protein ${ }^{a}$ & 54.47 & $\begin{array}{l}\text { Belongs to the Gram-negative porin family; outer membrane porin protein C } \\
\text { (phosphoporin PhoE) }\end{array}$ & 41 \\
\hline
\end{tabular}

${ }^{a}$ The predicted protein sequence was obtained using protein-BLAST against C. sakazakii; NCBI Reference Sequence: NZ_CP011047.1. 
from the same Cronobacter sequence type, ST7. This is the major C. malonaticus sequence type in the Cronobacter PubMLST database (Forsythe et al., 2014). Although C. malonaticus strains used in this study are from the same clonal complex (ST7) and therefore have high degree of genomic similarity, they showed differences in their motility and invasive properties (Table 1).

Two-dimensional SDS page coupled with mass spectrophotometry have been used to identify differently expressed virulence related proteins between C. sakazakii strains and therefore could be used to study the closely related species C. malonaticus (Du et al., 2015; Ye et al., 2015). In this study, OMPs of eight C. malonaticus strains were identified and characterized. The OMPs were identified by two different approaches; mass spectrometry (MALDI-TOF/TOF) of individual OMPs separated by 2D-PAGE profiles (Figure 2), "Bottom up" mass spectrometry (LC-MS/MS) of total OMPs in extraction of eight C. malonaticus strains (Table 2) and in bands separated by SDS-PAGE (Figure 4). The OMPs were isolated using Sarkosyl, the most powerful and commonly used approach in OMPs purification of Gram-negative bacteria (Jaradat et al., 2011; Muthiadin et al., 2015; Ferrer-Navarro et al., 2016). The SDS-PAGE profiles for the isolated OMPs of C. malonaticus strains (Figure 1) observed in this study were very similar to the OMP patterns detected by other researchers in other Cronobacter species and other Enterobacteriaceae members (Jaradat et al., 2011; Maiti et al., 2011). Overall, the data shows that the SDS-PAGE profiles for the isolated OMPs are similar in all of $C$. malonaticus strains with the majority of proteins range from $\sim 150$ to $30 \mathrm{kDa}$. However, a single protein band of size $\sim 29 \mathrm{kDa}$ appeared only in four C. malonaticus strains $(565,1556,1827$, and 2018). This suggested that the four strains differ in their surface proteins from the other $C$. malonaticus. Based on previous in vitro studies these strains were categorized as highly invasive. Furthermore, the strong clonailty within the strains did not give an answer to the observed difference, which made identifying this protein intriguing, as it may be a contributor to the invasion properties of the strains.

This finding was further investigated by identifying the OMPs profile of all eight $C$. malonaticus strains using mass spectrometry (LC-MS/MS). The data shows that the four highly invasive $C$. malonaticus strains share five flagellin-related proteins which include; flagellar hook protein FlgE, flagellar hook-associated protein 1, flagellar hook-associated protein, flagellin, and flagellar hook-filament junction protein FlgL (Table 3). SDSPAGE revealed that the band of size $\sim 29 \mathrm{kDa}$, which was shared by the four highly invasive C. malonaticus strains, was flagellin (FliC) (Figure 4, Table 4). The flagellin (FliC) is a major protein of bacterial flagella, which has been shown to have a crucial role in adhesion and invasion of pathogenic bacteria (Hofstra et al., 1980; Jaradat and Zawistowski, 1998; Haiko and Westerlund-Wikström, 2013). The same protein band of $29 \mathrm{kD}$ was previously detected and identified as flagelin in five different Cronobacter species using anti-flagella antibody coupled with mass spectrophotometry (Cruz-Córdova et al., 2012). It is also associated with auto-aggregation and biofilm formation (Hartmann et al., 2010; Hoeflinger and Miller, 2017). Flagellar hook-associated protein $1(\mathrm{FlgK})$ and flagellar hook protein (FlgE) of band size $\sim 58$ and $\sim 43 \mathrm{kDa}$, respectively, are two further proteins which shows to be specifically expressed in the highly invasive strains (Figure 4 and Table 4).

The comparative analysis of one highly invasive $C$. malonaticus strain (1827) and one low invasive strain (1830) was undertaken using the protein spots from 2D-PAGE. The data shows that two out of the nine protein spots (five and six; Figure 2) in the highly invasive C. malonaticus strain 1827 showed a significantly $(p$-value $<0.05) \geq 2.5$ fold increase compared to the low invasive strain 1830 (Table 2). The identity of these two protein spots was determined by MALDI-TOF/TOF mass spectrometer to be a beta-lactamase (SHV-6), a periplasmic component and flagellar protein export ATPase FliI. In contrast, three protein spots (one, three, and four) of the low invasive strain showed a significant $(p<0.05)$ decrease $(\geq 2$-fold $)$ compared to the highly invasive strain (1827). These proteins were also identified as cytoplasmic proteins (dihydroorotase and histidinol-phosphate transaminase), while one protein spot was a hypothetical protein with unknown function, which will be of significant interest in future studies. The presence of other protein including enolase and elongation factor thermo unstable (EF-Tu) is a common finding as they are considered as highly conserved protein that exists on the cell wall of many organisms including gram negative bacteria (Weijland et al., 1992; Diaz-Ramos et al., 2012).

In conclusion, this study has confirmed that flagellar proteins are present only in the highly invasive C. malonaticus strains and strongly correlate to their motility. The fact that flagellar proteins are of high importance in the adhesion and invasion of a pathogen supports the theory that the identified flagellar proteins could play a significant role in the invasive abilities of the adult pathovar C. malonaticus CC7.

\section{AUTHOR CONTRIBUTIONS}

MA, IA, FB, and AA designed and performed the experiments. MA, IA, and FB analyzed, interpreted the data, and drafted the manuscript. SF provided science direction, contributed to data interpretation, and provided manuscript editing.

\section{ACKNOWLEDGMENTS}

We would like to thank Dr. Phillip Bonner and Dr. Alan Hargreaves (Nottingham Trent University, UK) for their generosity in using their laboratory, their assistance was greatly appreciated. We also acknowledge the help provided by Dr. David Boocock and Dr. Clare Coveney (Jon van Geest Cancer Research Centre, Nottingham Trent University, $\mathrm{UK}$ ) in the proteomic analysis. Our additional thanks go to Dr. Naqash Mosood and Mohamed Saad Nottingham Trent University (UK) for their help with the bacterial cultures. 


\section{REFERENCES}

Aldova, E., Hausner, O., and Postupa, R. (1983). Tween esterase activity in Enterobacter sakazakii. Z. Bakteriol. Mikrobiol. Hyg. A 256, 103-108. doi: 10.1016/S0174-3031(83)80057-2

Almajed, F. S., and Forsythe, S. J. (2016). Cronobacter sakazakii clinical isolates overcome host barriers and evade the immune response. Microb. Pathog. 90, 55-63. doi: 10.1016/j.micpath.2015.11.014

Alsonosi, A. (2017). Identification of Physiological and Virulence Traits of Clinical Strains of Cronobacter malonaticus. Dissertation/Ph.D. thesis, Nottingham Trent University, Nottingham.

Alsonosi, A., Hariri, S., Kajsik, M., Orieskova, M., Hanulik, V., Roderova, M., et al. (2015). The speciation and genotyping of Cronobacter isolates from hospitalised patients. Eur. J. Clin. Microbiol. Infect. Dis. 34, 1979-1988. doi: 10.1007/s10096-015-2440-8

Alzahrani, H., Winter, J., Boocock, D., De Girolamo, L., and Forsythe, S. J. (2015). Characterization of outer membrane vesicles from a neonatal meningitic strain of Cronobacter sakazakii. FEMS Microbiol. Lett. 362:fnv085. doi: 10.1093/femsle/fnv085

Biering, G., Karlsson, S., Clark, N. C., Jonsdottir, K. E., Ludvigsson, P., and Steingrimsson, O. (1989). Three cases of neonatal meningitis caused by Enterobacter sakazakii in powdered milk. J. Clin. Microbiol. 27, 2054-2056.

Caubilla-Barron, J., Hurrell, E., Townsend, S., Cheetham, P., Loc-Carrillo, C., Fayet, O., et al. (2007). Genotypic and phenotypic analysis of Enterobacter sakazakii strains from an outbreak resulting in fatalities in a neonatal intensive care unit in France. J. Clin. Microbiol. 45, 3979-3985. doi: 10.1128/JCM.01075-07

Cetinkaya, E., Joseph, S., Ayhan, K., and Forsythe, S. J. (2013). Comparison of methods for the microbiological identification and profiling of Cronobacter species from ingredients used in the preparation of infant formula. Mol. Cell. Probes 27, 60-64. doi: 10.1016/j.mcp.2012.10.003

Cottrell, J. S. (2011). Protein identification using MS/MS data. J. Proteomics 74, 1842-1851. doi: 10.1016/j.jprot.2011.05.014

Cruz-Córdova, A., Rocha-Ramirez, L. M., Ochoa, S. A., Gonzalez-Pedrajo, B., Espinosa, N., Eslava, C., et al. (2012). Flagella from five Cronobacter species induce pro-inflammatory cytokines in macrophage derivatives from human monocytes. PLoS ONE 7:E52091. doi: 10.1371/journal.pone.0052091

Diaz-Ramos, A., Roig-Borrellas, A., Garcia-Melero, A., and Lopez-Alemany, R. (2012). $\alpha$ Enolase, a multifunctional protein: its role on pathophysiological situations. J. Biomed. Biotechnol. 2012:156795. doi: 10.1155/2012/156795

Du, X. J., Han, R., Li, P., and Wang, S. (2015). Comparative proteomic analysis of Cronobacter sakazakii isolates with different virulences. J. Proteomics 128, 344-351. doi: 10.1016/j.jprot.2015.08.013

Farmer, J. J., Asbury, M. A., Hickman, F. W., Brenner, D. J., and The Enterobacteriaceae Study Group. (1980). Enterobacter sakazakii: a new species of "Enterobacteriaceae" isolated from clinical specimens. Int. J. Syst. Evol. Microbiol. 30, 569-584. doi: 10.1099/00207713-30-3-569

Ferrer-Navarro, M., Balleste-Delpierre, C., Vila, J., and Fabrega, A. (2016). Characterization of the outer membrane subproteome of the virulent strain Salmonella Typhimurium SL1344. J. Proteomics 146, 141-147. doi: 10.1016/j.jprot.2016.06.032

Forsythe, S. J., Dickins, B., and Jolley, K. A. (2014). Cronobacter, the emergent bacterial pathogen Enterobacter sakazakii comes of age; MLST and whole genome sequence analysis. BMC Genomics 15:1121. doi: 10.1186/1471-2164-15-1121

Friedemann, M. (2007). Enterobacter sakazakii in food and beverages (other than infant formula and milk powder). Int. J. Food Microbiol. 116, 1-10. doi: $10.1016 /$ j.ijfoodmicro.2006.12.018

Giri, C. P., Shima, K., Tall, B. D., Curtis, S., Sathyamoorthy, V., Hanisch, B., et al. (2012). Cronobacter spp. (previously Enterobacter sakazakii) invade and translocate across both cultured human intestinal epithelial cells and human brain microvascular endothelial cells. Microb. Pathog. 52, 140-147. doi: 10.1016/j.micpath.2011.10.003

Haiko, J., and Westerlund-Wikström, B. (2013). The role of the bacterial flagellum in adhesion and virulence. Biology 2, 1242-1267. doi: 10.3390/biology2041242

Hariri, S., Joseph, S., and Forsythe, S. J. (2013). Cronobacter sakazakii ST4 strains and neonatal meningitis, United States. Emerg. Infect. Dis. 19, 175-177. doi: 10.3201/eid1901.120649
Hartmann, I., Carranza, P., Lehner, A., Stephan, R., Eberl, L., and Riedel, K. (2010) Genes involved in Cronobacter sakazakii biofilm formation. Appl. Environ. Microbiol. 76, 2251-2261. doi: 10.1128/AEM.00930-09

Hoeflinger, J. L., and Miller, M. J. (2017). Cronobacter sakazakii ATCC 29544 autoaggregation requires FliC flagellation, not motility. Front. Microbiol. 8:301. doi: $10.3389 /$ fmicb. 2017.00301

Hofstra, H., Van Tol, J. D., and Dankert, J. (1980). Cross-reactivity of major outer membrane proteins of Enterobacteriaceae, studied by crossed immunoelectrophoresis. J. Bacteriol. 143, 328-337.

Holy, O., and Forsythe, S. (2014). Cronobacter spp. as emerging causes of healthcare-associated infection. J. Hosp. Infect. 86, 169-177. doi: 10.1016/j.jhin.2013.09.011

Holy, O., Petrzelova, J., Hanulik, V., Chroma, M., Matouskova, I., and Forsythe, S. J. (2014). Epidemiology of Cronobacter spp. isolates from patients admitted to the Olomouc University Hospital (Czech Republic). Epidemiol. Mikrobiol. Imunol. 63, 69-72.

Hurrell, E., Kucerova, E., Loughlin, M., Caubilla-Barron, J., Hilton, A., Armstrong, R., et al. (2009). Neonatal enteral feeding tubes as loci for colonisation by members of the Enterobacteriaceae. BMC Infect. Dis. 9:146. doi: 10.1186/1471-2334-9-146

Iversen, C., and Forsythe, S. (2003). Risk profile of Enterobacter sakazakii, an emergent pathogen associated with infant milk formula. Trends Food Sci. Technol. 14, 443-454. doi: 10.1016/S0924-2244(03)00155-9

Iversen, C., Mullane, N., McCardell, B., Tall, B. D., Lehner, A., Fanning, S., et al. (2008). Cronobacter gen. nov., a new genus to accommodate the biogroups of Enterobacter sakazakii, and proposal of Cronobacter sakazakii gen. nov., comb. nov., Cronobacter malonaticus sp. nov., Cronobacter turicensis sp. nov., Cronobacter muytjensii sp. nov., Cronobacter dublinensis sp. nov., Cronobacter genomospecies 1, and of three subspecies, Cronobacter dublinensis subsp. dublinensis subsp. nov., Cronobacter dublinensis subsp. lausannensis subsp. nov. and Cronobacter dublinensis subsp. lactaridi subsp. nov. Int. J. Syst. Evol. Microbiol. 58(Pt 6), 1442-1447. doi: 10.1099/ijs.0.65577-0

Jaradat, Z. W., Rashdan, A. M., Ababneh, Q. O., Jaradat, S. A., and Bhunia, A. K. (2011). Characterization of surface proteins of Cronobacter muytjensii using monoclonal antibodies and MALDI-TOF Mass spectrometry. BMC Microbiol. 11:148. doi: 10.1186/1471-2180-11-148

Jaradat, Z. W., and Zawistowski, J. (1998). Antigenically stable $35 \mathrm{kDa}$ outer membrane protein of Salmonella. Food Agric. Immunol. 10, 259-270. doi: 10.1080/09540109809354989

Joseph, S., and Forsythe, S. J. (2011). Predominance of Cronobacter sakazakii sequence type 4 in neonatal infections. Emerg. Infect. Dis. 17, 1713-1715. doi: 10.3201/eid1709.110260

Kandhai, M. C., Reij, M. W., Gorris, L. G., Guillaume-Gentil, O., and van Schothorst, M. (2004). Occurrence of Enterobacter sakazakii in food production environments and households. Lancet 363, 39-40. doi: 10.1016/S0140-6736(03)15169-0

Kucerova, E., Joseph, S., and Forsythe, S. (2011). The Cronobacter genus: ubiquity and diversity. Qual. Assur. Saf. Crops Foods 3, 104-122. doi: 10.1111/j.1757-837X.2011.00104.x

Laemmli, U. K. (1970). Cleavage of structural proteins during the assembly of the head of bacteriophage T4. Nature 227, 680-685. doi: 10.1038/22 $7680 \mathrm{a} 0$

Lai, K. K. (2001). Enterobacter sakazakii infections among neonates, infants, children, and adults. Case reports and a review of the literature. Medicine 80, 113-122. doi: 10.1097/00005792-200103000-00004

Maiti, B., Shetty, M., Shekar, M., and Karunasagar, I. (2011). Recombinant outer membrane protein A (OmpA) of Edwardsiella tarda, a potential vaccine candidate for fish, common carp. Microbiol. Res. 167, 1-7. doi: 10.1016/j.micres.2011.02.002

Miled-Bennour, R., Ells, T. C., Pagotto, F. J., Farber, J. M., Kerouanton, A., Meheut, T., et al. (2010). Genotypic and phenotypic characterisation of a collection of Cronobacter (Enterobacter sakazakii) isolates. Int. J. Food Microbiol. 139, 116-125. doi: 10.1016/j.ijfoodmicro.2010.01.045

Muthiadin, C., Natsir, R., Agus, R., Nasrum, M., Dwiyanti, R., Sabir, M., et al. (2015). Identification and characterization of antigenic $36 \mathrm{Kda}$ Outer Membrane Protein (OMP) of Salmonella enterica serovar from Makassar, South Sulawesi, Indonesia. Am. J. Biomed. Res. 3, 9-12. doi: 10.12691/ ajbr-3-1-3 
Nirmalan, N., Sims, P. F., and Hyde, J. E. (2004). Quantitative proteomics of the human malaria parasite Plasmodium falciparum and its application to studies of development and inhibition. Mol. Microbiol. 52, 1187-1199. doi: 10.1111/j.1365-2958.2004.04049.x

Patrick, M. E., Mahon, B. E., Greene, S. A., Rounds, J., Cronquist, A., Wymore, K., et al. (2014). Incidence of Cronobacter spp. infections, United States, 2003-2009. Emerg. Infect. Dis. 20, 1520-1523. doi: 10.3201/eid2009.140545

Sonbol, H., Joseph, S., McAuley, C. M., Craven, H. M., and Forsythe, S. J. (2013). Multilocus sequence typing of Cronobacter spp. from powdered infant formula and milk powder production factories. Int. Dairy J. 30, 1-7. doi: 10.1016/j.idairyj.2012.11.004

Stoscheck, C. M. (1990). Quantitation of protein. Methods Enzymol. 182, 50-68. doi: 10.1016/0076-6879(90)82008-P

Townsend, S., Hurrell, E., and Forsythe, S. (2008). Virulence studies of Enterobacter sakazakii isolates associated with a neonatal intensive care unit outbreak. BMC Microbiol. 8:64. doi: 10.1186/1471-2180-8-64

Townsend, S. M., Hurrell, E., Gonzalez-Gomez, I., Lowe, J., Frye, J. G., Forsythe, S., et al. (2007). Enterobacter sakazakii invades brain capillary endothelial cells, persists in human macrophages influencing cytokine secretion and induces severe brain pathology in the neonatal rat. Microbiology 153(Pt 10), 3538-3547. doi: $10.1099 /$ mic. $0.2007 / 009316-0$
Weijland, A., Harmark, K., Cool, R. H., Anborgh, P. H., and Parmeggiani, A. (1992). Elongation factor Tu: a molecular switch in protein biosynthesis. $\mathrm{Mol}$ Microbiol. 6, 683-688. doi: 10.1111/j.1365-2958.1992.tb01516.x

Ye, Y., Gao, J., Jiao, R., Li, H., Wu, Q., Zhang, J., et al. (2015). The membrane proteins involved in virulence of Cronobacter sakazaki virulent G362 and attenuated L3101 isolates. Front. Microbiol. 6:1238. doi: $10.3389 /$ fmicb. 2015.01238

Conflict of Interest Statement: The authors declare that the research was conducted in the absence of any commercial or financial relationships that could be construed as a potential conflict of interest.

The handling Editor declared a past co-authorship with one of the authors SF.

Copyright (C) 2017 Aldubyan, Almami, Benslimane, Alsonosi and Forsythe. This is an open-access article distributed under the terms of the Creative Commons Attribution License (CC BY). The use, distribution or reproduction in other forums is permitted, provided the original author(s) or licensor are credited and that the original publication in this journal is cited, in accordance with accepted academic practice. No use, distribution or reproduction is permitted which does not comply with these terms. 